\title{
18. CALCAREOUS NANNOFOSSILS FROM SITES 815 AND 817: SOME PALEOCEANOGRAPHIC CONSIDERATIONS ${ }^{1}$
}

\author{
Stefan Gartner ${ }^{2}$ and Vita Pariente ${ }^{2}$
}

\begin{abstract}
An evaluation of size-frequency distribution of reticulofenestrid coccoliths in the upper Miocene through Pleistocene sediments at Sites 815 and 817 suggests that phytoplankton productivity has been moderately high in this area, with modest but significant fluctuations. At both sites, productivity was enhanced during the middle part of the late Miocene, but diminished somewhat across the Miocene/Pliocene boundary. Enhanced productivity occurred again during the middle part of the early Pliocene, but during the early part of the late Pliocene productivity declined. Productivity was enhanced during the latest Pliocene and fluctuated episodically during the Pleistocene. During the late Miocene and early Pliocene, the timing of inferred productivity fluctuations corresponded with the timing of sea-level fluctuations inferred from carbonate content and total nannofossil abundance, which suggests that the two are probably linked; however, the middle Pliocene and late Pliocene are difficult to interpret because the record may be distorted by deposition from contour currents.
\end{abstract}

\section{INTRODUCTION}

Calcareous nannofossils generally are regarded as excellent tools in biostratigraphy and have been widely exploited for this purpose. They have been used much less for interpreting past ocean conditions and the changes that have occurred through time in the ocean environment. Several early efforts, mainly with Pleistocene-Holocene coccolithophores, seemed to point the way (e.g., McIntyre and Bé, 1967; Roche et al., 1975; Okada and Honjo, 1973; Honjo and Okada, 1974; McIntyre et al., 1970; Geitzenauer et al., 1976). These studies were directed mainly at relating coccolithophore assemblages to ocean temperatures. Other studies (e.g., McIntyre and McIntyre, 1971; Schneiderman, 1973; Roth and Berger, 1975) sought to extract deep-ocean carbonate dissolution histories from fossil coccolith assemblages. Largescale paleoceanographic interpretations based on nannofossils were attempted by other investigators such as Haq (1980) and Lohman and Carlson (1981) as part of the Cenozoic Paleoceanography (CENOP) study. More recently, Beaufort and Aubry (1990) attempted to use the variations in the ratio of two common and long-ranging coccolith genera, Coccolithus and Reticulofenestra, to monitor environmental changes during the late Miocene of the South Atlantic Ocean.

The above studies were hampered seriously by an inadequate understanding of what variables in the environment are recorded by the calcareous nannoplankton. Few detailed studies have been done of modern coccolithophore assemblages in which environmental variables also are documented. A notable exception is the study of Okada and Honjo (1973) in which are documented calcareous nannoplankton from a Pacific Ocean north-south transect and for which detailed hydrographic data also are available (Marumo, 1970). Unfortunately, those data have not been evaluated properly. Moreover, because the sampling was done only once, it is not clear how representative the data are. Consequently, all paleoceanographic interpretations of fossil coccolith assemblages remain tentative and somewhat speculative.

With few exceptions, attempts to interpret past ocean environments from calcareous phytoplankton remains have been focused almost entirely on ocean surface temperature. Although temperature is clearly a limiting factor to coccolithophore distribution in high latitudes, the more moderate temperature changes in tropical and subtropical lati-

\footnotetext{
'McKenzie, J.A., Davies, P.J., Palmer-Julson, A., et al., 1993. Proc. ODP. Sci. Results, 133: College Station, TX (Ocean Drilling Program).

${ }^{2}$ Department of Oceanography, Texas A\&M University, College Station, TX 77843.
}

tudes seem to be unimportant to the organisms. Rather, factors other than temperature must be controlling the distribution of modern coccolithophores (compare, e.g., figs. 2, 7, 8, and 10 in Okada and Honjo, 1973). Modern assemblages extend geographically across temperature boundaries, such as might occur seasonally over tropical and subtropical latitudes, as well as temperature changes that may reasonably be inferred for the late Cenozoic in tropical and subtropical oceans.

Much more important to coccolithophores than water temperature (within the limits of possible low- and mid-latitude ocean surface temperatures) is the concentration of nutrients in the photic water column (see, e.g., data of Okada and Honjo, 1973; and Marumo, 1970). Consequently, it is productivity that will be reflected in the phytoplankton and, ultimately, in the coccoliths that have accumulated in the sediment. Among the modern coccolithophores, one- the lower photic zone species Florisphaera profunda - has a preference for nutrientrich waters. An increase in abundance of this species has been interpreted to signal a rise toward the surface of the nutricline (Molfino and McIntyre, 1990). Unfortunately, this species has not been widely recorded in studies of Neogene pelagic sediments; hence, its range and geographic distribution are not known. A more useful group comprises the reticulofenestrids, a group that includes the bulk of all coccoliths in Neogene sediments. The reticulofenestrids include several similar genera, among them: the dominant modern genus Emiliania, the most important Pleistocene genus Gephyrocapsa, and the two common genera Pseudoemiliania and Reticulofenestra (including Crenalithus). Two of these genera, Gephyrocapsa and Reticulofenestra, differ only in that the former always has a distinct diagonal bar or bridge spanning the central opening. Both genera are represented by several species that differ from one another principally by their size. In each genus, the smallest species may be less than $1 \mu \mathrm{m}$ in maximum dimension, but the largest may measure 10 times that. Among the modern Gephyrocapsa, great numbers of the small coccoliths are associated with productive coastal and shelf areas, as well as with high-productivity regions in the open ocean. The large species are much more common away from coastal regions and dominate in the oligotrophic waters of oceanic gyres (for a summary, see Gartner, 1988).

\section{MATERIALS AND METHODS}

The sediments recovered during Leg 133 have some properties that make a paleoceanographic evaluation desirable. These sediments were deposited in a carbonate environment, where selective dissolution is not likely to be a serious problem; the sedimentation rate, though variable, is relatively high, and the record is expanded and 
detailed; biostratigraphic control is excellent, even over intervals where displaced sediments occur; and significant hiatuses are few and can be clearly identified.

For this study, two parameters were documented and evaluated: (1) the abundance of calcareous nannofossils in the sediment (i.e., a measure of the pelagic vs. nonpelagic sedimentation) and (2) the size-frequency distribution of the dominant coccoliths, the reticulofenestrids (genus Reticulofenestra, Crenalithus, Pseudoemiliania, Gephyrocapsa, and Emiliania), in the sediment. The amount of pelagic component contributed to the sediment is determined by productivity. In a setting along a continental margin, however, the proportion of the pelagic component in the sediment is determined by the amount of dilution by the nonpelagic component of the sediment. In the case of the northeastern Australian margin, two sources of diluent can be identified: siliciclastic sediments derived from adjacent land areas, and calcareous sediments shed from nearby reefs and carbonate platforms. The former would be most prominent when sea level was dropping or at lowstands, and land-derived clastics would be transported to the shelf edge and beyond; in this case, to the edge of the deep channels that separate the Queensland Plateau from Australia. When sea level is rising and during highstands of sea level, land-derived siliciclastic sediments are trapped in lagoons behind the reef and little is transported into deeper water beyond the reef.

According to current models, deep-water accumulation of reefand bank-derived carbonate particles would be the inverse. Maximum production and shedding would occur when the platforms are inundated during highstands of sea level, whereas a lowstand of sea level would expose the carbonate-producing area, curtailing production and, hence, its supply to the hemipelagic realm nearby. (For a review, see Droxler et al., this volume.) Thus, the abundance of nannofossils is modulated by the above three variables: productivity, siliciclastic sedimentation (when sea level is low), and detrital carbonate sedimentation (when sea level is high). Productivity is monitored by the size-frequency distribution of reticulofenestrid coccoliths; pelagic vs. nonpelagic sedimentation is monitored by the proportion of coccoliths (pelagic component) in the sediment; and siliciclastic vs. detrital carbonate dilution is monitored by the carbonate content of the sediment. These three variables have been plotted for Holes $815 \mathrm{~A}$ and $817 \mathrm{~A}$ in Figures 1 and 2, respectively.

Size-frequency distributions have been plotted as stacked histograms. Each histogram is based on 25 measured specimens, which represent the first 25 reticulofenestrid coccoliths encountered in successive random fields on smear slides. Sample spacing has been arranged to reflect sedimentation rate; size-frequency distributions were determined for every section $(1.5 \mathrm{~m})$ in low-sedimentation rate intervals and for every core $(9.5 \mathrm{~m})$ for high-sedimentation rate intervals, as determined from the succession of nannofossil biohorizons. The vertical scale bar in each histogram represents $100 \%$. On the horizontal scale, each unit represents $0.635 \mu \mathrm{m}$, and the scale length extends from $2(1.27 \mu \mathrm{m})$ to 13 units $(8.25 \mu \mathrm{m})$. The stacked histograms indicate that the reticulofenestrids, indeed the entire nannofossil assemblages at both sites, are overwhelmingly dominated by small specimens (i.e., small coccoliths). Few of the coccoliths in these samples are larger than $5 \mu \mathrm{m}$, which suggests that calcareous phytoplankton productivity was generally high in the area from the late Miocene to the early Pleistocene. Significant shifts are seen in the dominant reticulofenestrid size categories, and these shifts do not occur at levels where reticulofenestrid species became extinct or first appeared. The shifts, therefore, must reflect changes in the environment, probably fluctuations in productivity.

The data from the size-frequency determinations also were used to calculate a mean maximum diameter of reticulofenestrids for each sample; these values have been plotted in the center of Figures 1 and 2. The overall mean (indicated by the dashed line in each plot) is significantly different for the two sites: $4.5(2.86 \mu \mathrm{m})$ for Hole $815 \mathrm{~A}$ and $5(3.17 \mu \mathrm{m})$ for Hole 817A.
Nannofossil abundance has been plotted as the estimated percentage of the sediment that consists of coccoliths and associated nannofossils. The two lines represent the actual estimates (thin line) and a three-point moving average (heavy line). The dashed line represents the mean of all estimates for the core and is for reference purposes. The calcium carbonate content of the sediment was taken from shipboard data and has been plotted on the right of each figure. The dashed line represents the mean of all values over the interval of the plot.

\section{SITE 815}

The sediments at this site show a strong pelagic influence from the sediment/water interface to about $410 \mathrm{mbsf}$, which includes the upper Miocene, Pliocene, and Pleistocene-Holocene. Below that, nannofossils are relatively rare and are not representative of pelagic sedimentation. At 410 mbsf, nannofossils increase sharply and carbonate content decreases, which signals an abrupt transition from a shallowwater carbonate environment to a hemipelagic setting. The interval from 410 to about $355 \mathrm{mbsf}$ is of late Miocene age. Carbonate content fluctuates narrowly about an average of $70 \%$, whereas the proportion of nannofossils is well above average (average $=\sim 70 \%$ ), and the mean diameter of reticulofenestrid placoliths is average to slightly below average, suggesting an episode of generally productive surface waters centered over the interval of occurrence of Amaurolithus amplificus. Immediately below and above the Miocene/Pliocene boundary, which is at about $353 \mathrm{mbsf}$, the carbonate content changes little, and nannofossil content of the sediment peaks. The mean size of the reticulofenestrids increases slightly, probably signaling a slight increase in pelagic influence. From 340 to about 280 mbsf, within the early Pliocene and spanning the range of Amaurolithus tricorniculatus, reticulofenestrid mean diameter is below average, suggesting enhanced productivity, although nannofossil content and carbonate content decline toward the top of this interval.

The interval from 310 to about 40 mbsf is a greatly expanded middle Pliocene section. In the lower part of this interval- to the midpoint of the Pliocene at about $158 \mathrm{mbsf}$-mean reticulofenestrid diameter is average and carbonate content is slightly below average. The proportion of nannofossils in the sediment fluctuates from near average at 290 to $245 \mathrm{mbsf}$, to slightly above average at 245 to 210 mbsf, to below average from 210 mbsf upward to the middle Pliocene and beyond. From the midpoint of the Pliocene, the reticulofenestrid mean diameter is consistently higher than average, to about $70 \mathrm{mbsf}$, indicating a somewhat lowered productivity and/or more oceanic influence, but declines sharply above that in the uppermost upper Pliocene. The proportion of nannofossils in the sediment remains generally low, except at 60 to $40 \mathrm{mbsf}$, although the carbonate content generally increases from the middle Pliocene level forward. The interpretation of these changes, especially the middle Pliocene record, is complicated by the influence of contour current deposition and the probability of particle sorting associated with it.

\section{SITE 817}

At this site, too, the sediment shows strong pelagic influence from the Holocene back into the early Miocene, from 0 to about $200 \mathrm{mbsf}$. Carbonate sediments dominate (average 94.8\%), and significant noncarbonate dilution is present only in the upper Miocene and lower Pliocene interval. Nannofossil abundance in the sediment fluctuates greatly, and because siliciclastic diluents are minimal, the pelagic component must be diluted by bank-derived carbonates. Based on the dominance of small reticulofenestrids, productivity is judged to have been relatively high over the entire interval of dominantly pelagic sedimentation. The plot of reticulofenestrid size-frequency distribution and mean maximum diameter suggests two possible episodes of enhanced productivity during the late Miocene, one centered on the lower limit of the range of Amaurolithus amplificus, and the second 


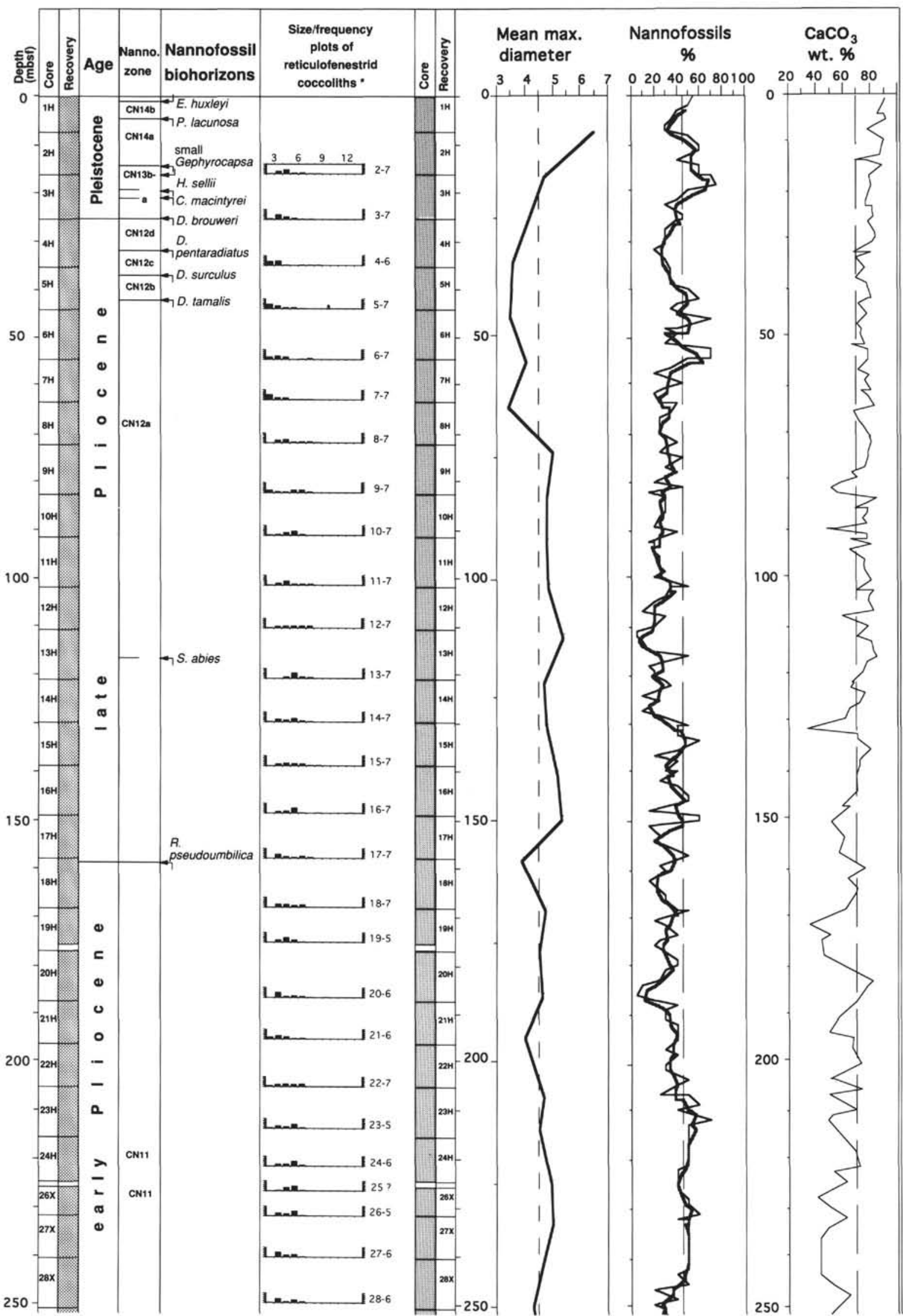

Figure 1. Plots of size/frequency and mean maximum diameter for Hole 815A combined with nannofossil biochronology, nannofossil abundance, and carbonate content of the sediment. In the size/frequency plots, the vertical scale represents $100 \%$; the horizontal scale is in arbitrary units equal to $0.63 \mu \mathrm{m}$. In the column labeled "Nannofossils \%," the thin line represents actual abundance estimates; the heavy line represents a 3-point moving average. 


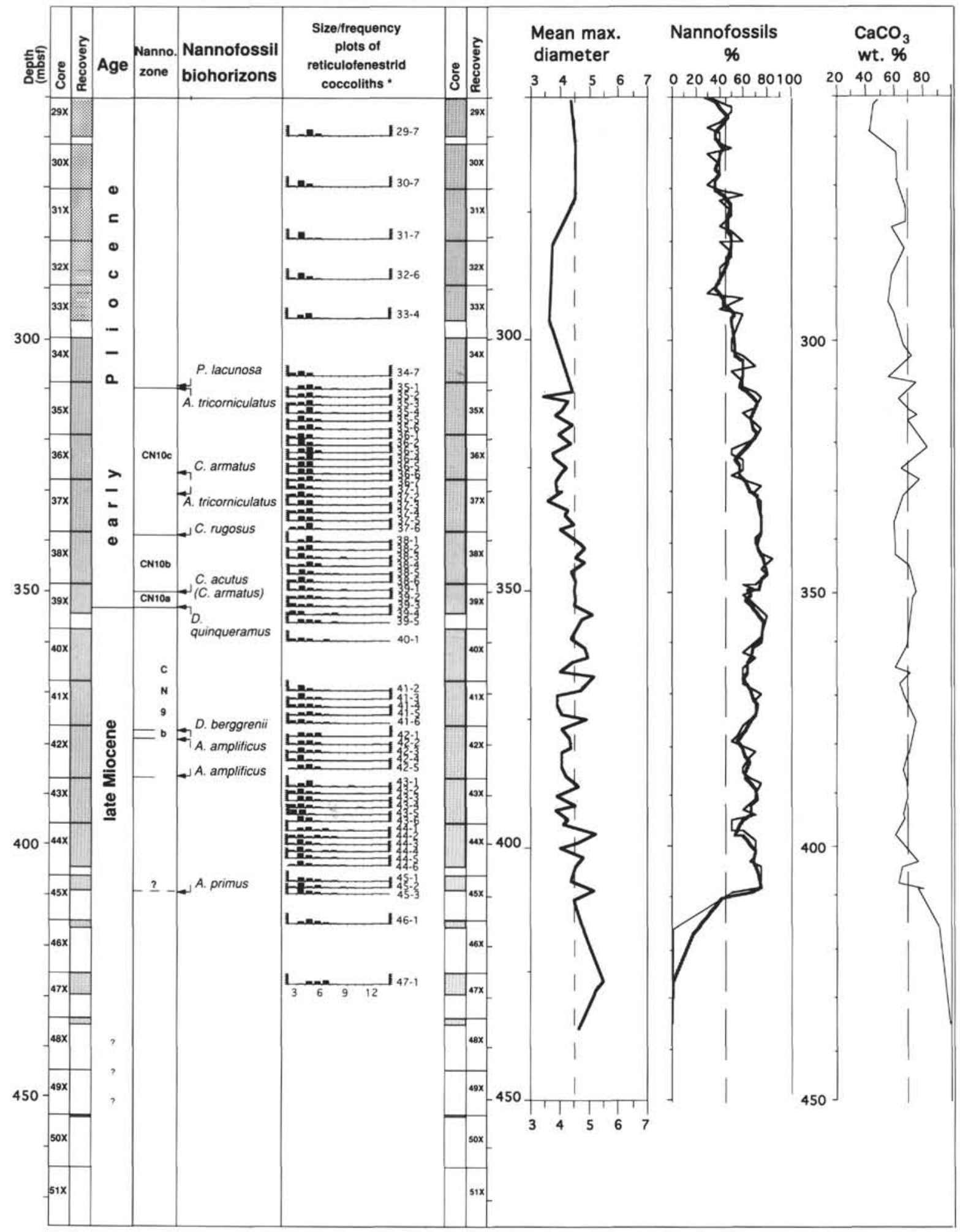

Figure 1 (continued). 


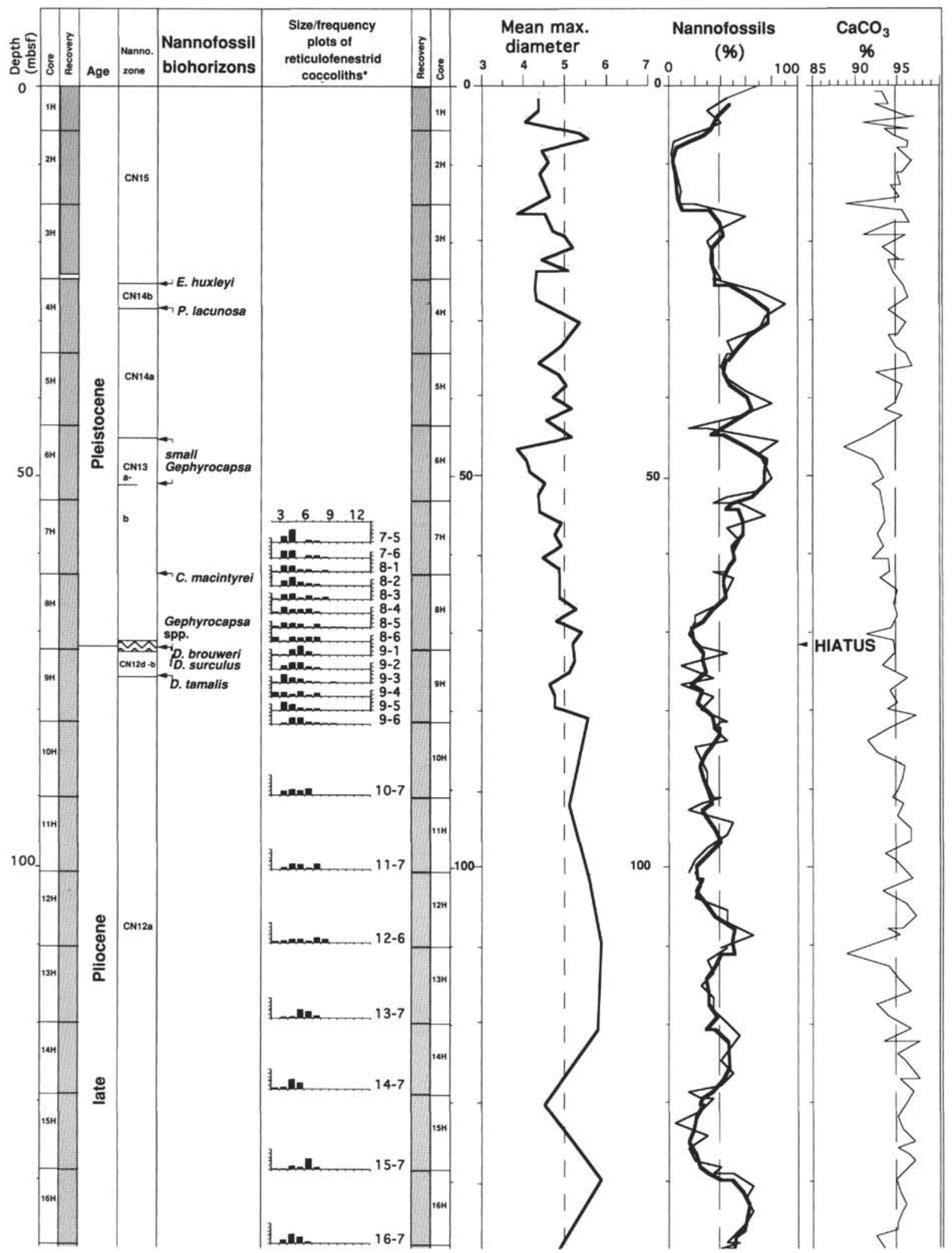

Figure 2. Plots of size/frequency and mean maximum diameter for Hole 817A combined with nannofossil biochronology, nannofossil abundance, and carbonate content of the sediment. In the size/frequency plots, the vertical scale represents $100 \%$; the horizontal scale is in arbitrary units equal to $0.63 \mu \mathrm{m}$. In the column labeled "Nannofossils \%," the thin line represents actual abundance estimates; the heavy line represents a 3-point moving average. 


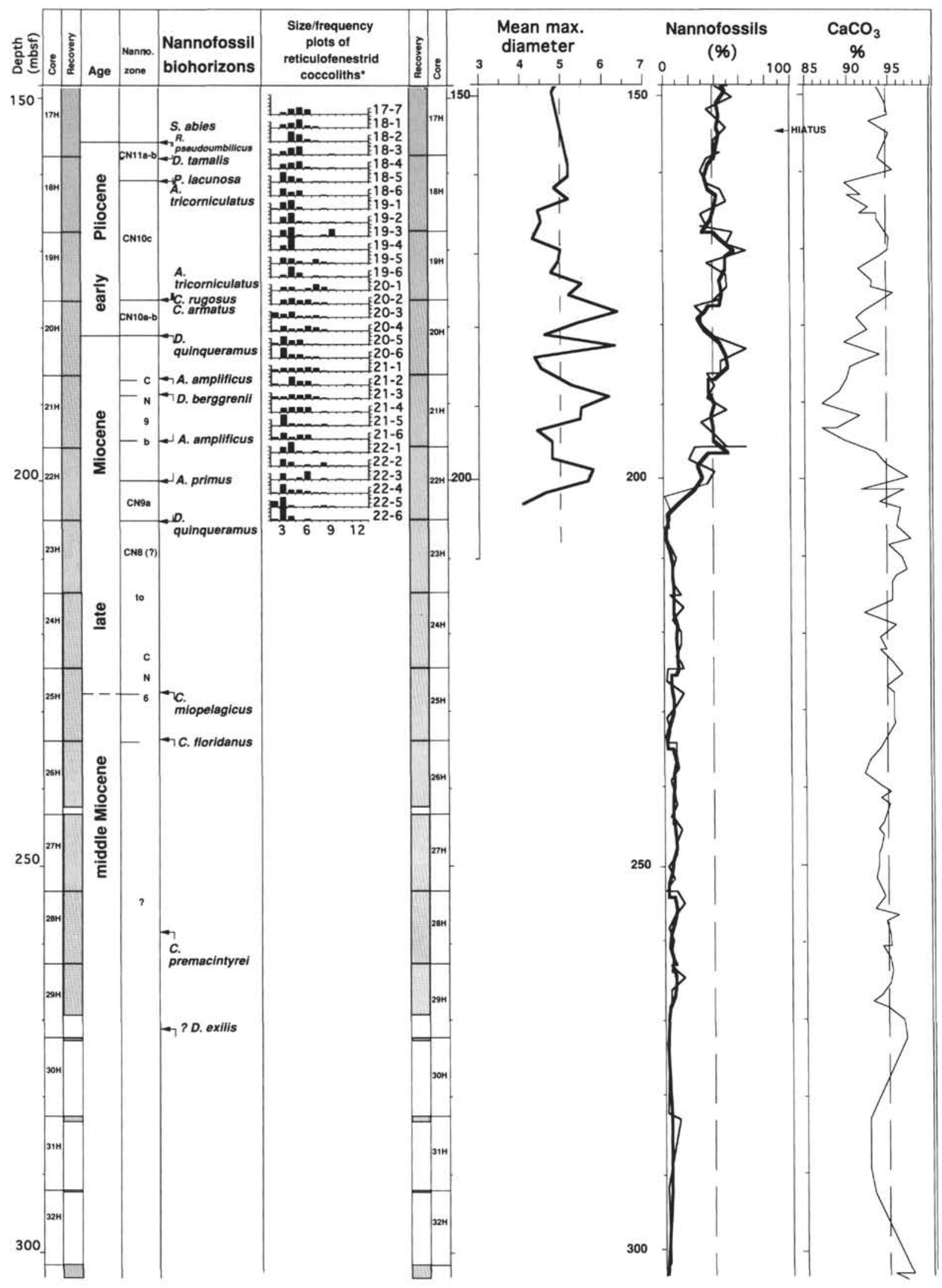

Figure 2 (continued). 
between the highest occurrence of that species and the highest occurrence of Discoaster quinqueramus. A similar episode can be seen in the middle part of a condensed early Pliocene interval (164-170 mbsf), centered on the range of Amaurolithus tricorniculatus.

From 80 to about 145 mbsf, the mean maximum reticulofenestrid diameter is greater, and an interval of reduced productivity is inferred. Nannofossil abundance also is reduced, and, in the absence of a noncarbonate diluent, carbonate shedding from nearby banks is inferred. Above $80 \mathrm{mbsf}$, the reticulofenestrid mean maximum diameter makes several excursions into the small Gephyrocapsa dominance interval (see, e.g., Gartner, 1988). The most important occurrence is centered at $50 \mathrm{mbsf}$, which corresponds to the middle Pleistocene episode of enhanced productivity in many parts of the Earth's oceans. Significantly, the proportion of nannofossils in the sediment is higher at this level, as is the amount of noncalcareous diluent in the sediment.

The record from Hole $817 \mathrm{~A}$ may show a reasonably good correspondence between inferred productivity and inferred relative sealevel stands, especially for the late Miocene, the early Pliocene, and the middle Pleistocene. The late Pliocene record is not clear and, in any case, would be suspect because the contour currents responsible for deposition of this thick pile of sediments also must have caused a certain amount of sorting of sediment particles.

\section{CONCLUSIONS}

Comparison of the records from the two sites is difficult, especially over the intervals where sedimentation rates differed significantly. What seems clear is that, although pelagic productivity generally remained fairly high throughout the late Miocene-Pliocene-Pleistocene in this area, the late Miocene was characterized by significant fluctuations, with episodes of enhanced productivity occurring from above the lowest occurrence of Amaurolithus primus forward to just below the Miocene/Pliocene boundary. In the early Pliocene both sites show an episode of enhanced productivity centered approximately on the range of Amaurolithus tricorniculatus. Above that the record should be viewed with caution because of the possibility of distortion by contour current deposition. In the late Pliocene, there appears to be an episode of reduced productivity, which commenced at both sites near the midpoint of the Pliocene and terminated at both just before the extinction of Discoaster tamalis (=2.6 m.y., Berggren et al., 1985). At both sites productivity seemingly increased in the late Pliocene. This changeover comes close to, but apparently predates slightly, the onset of significant Northern Hemisphere ice accumulation, which is placed closer to 2.5 m.y. (e.g., Zimmerman et al., 1984) and which might be expected to leave some influence on the sedimentary record even in this far-removed tropical setting.

The relationship between sediment composition (carbonate content, pelagic component), inferred sea-level change, and inferred productivity seems quite strong where sedimentation rate is not greatly distorted. The most serious obstacle to interpreting the record from this area is that redeposition by contour currents may have altered the composition of the nannofossil assemblage by sorting of component species, although there is no biostratigraphic evidence of erosion and redeposition of significant amounts of older sediments.

\section{ACKNOWLEDGMENTS}

The conscientious and thoughtful reviews of Katharina von Salis and Domenico Rio are gratefully acknowledged, as is the editorial assistance of Sondra Stewart.

\section{REFERENCES $*$}

Beaufort, L., and Aubry, M.-P., 1990. Fluctuations in the composition of late Miocene calcareous nannofossil assemblages as a response to orbital forcing. Paleoceanography, 5:845-865.

Berggren, W.A., Kent, D.V., and Van Couvering, J.A., 1985. The Neogene: Part 2. Neogene geochronology and chronostratigraphy. In Snelling, N.J. (Ed.), The Chronology of the Geological Record. Geol. Soc. London Mem., 10:211-260.

Gartner, S., 1988. Paleoceanography of the Mid-Pleistocene. Mar. Micropaleontol., 13:23-46.

Geitzenauer, K.R., Roche, M.B., and McIntyre, A., 1976. Modern Pacific coccolith assemblages: derivation and application to late Pleistocene paleotemperature analysis. In Cline, R.M., and Hays, J.D. (Eds.), Investigation of Late Quaternary Paleoceanography and Paleoclimatology. Mem.Geol. Soc. Am., 145:423-448.

Haq, B.U., 1980. Biogeographic history of Miocene calcareous nannoplankton and paleoceanography of the Atlantic Ocean. Micropaleontology, 26:414443.

Honjo, S., and Okada, H., 1974. Community structure of coccolithophores in the photic layer of the mid-Pacific. Micropaleontology, 20:209-230.

Lohman, G.P., and Carlson, J.J., 1981. Oceanographic significance of Pacific late Miocene calcareous nannoplankton. Mar. Micropaleontol., 6:553-579.

Marumo, R., 1970. Preliminary report of the Hakuho Maru Cruise KH- 69-04 (IBP cruise), August 12-November 13, 1969: the North and Equatorial Pacific Ocean. Ocean Res. Inst., Univ. Tokyo.

McIntyre, A., and Bé, A.W.H., 1967. Modern coccolithophoridae of the Atlantic Ocean. I: placoliths and cyrtoliths. Deep-Sea Res. Part A, 14:561-597.

McIntyre, A., Bé, A.W.H., and Roche, M.B., 1970. Modern Pacific coccolithophorida: a paleontological thermometer. Trans. N.Y. Acad. Sci., 32:720-731.

McIntyre, A., and McIntyre, R., 1971. Coccolith concentrations and differential solution in oceanic sediments. In Funnel, B.M., and Riedel, W.R. (Eds.), The Micropaleontology of Oceans: London (Cambridge Univ. Press), 253-261.

Molfino, B., and McIntyre, A., 1990. Nutricline variations in the equatorial Atlantic coincident with the Younger Dryas. Paleoceanography, 5:9971008.

Okada, H., and Honjo, S., 1973. The distribution of oceanic coccolithophorids in the Pacific. Deep-Sea Res. Part A, 20:355-374.

Roche, M.B., McIntyre, A., and Imbrie, J., 1975. Quantitative paleoceanography of the Late Pleistocene-Holocene North Atlantic. In Saito, T., and Burkle, L.H. (Eds.), Late Neogene Epoch Boundaries. Micropaleontology, Spec. Publ., 1:199-225.

Roth, P.H., and Berger, W.H., 1975. Distribution and dissolution of coccoliths in the south and central Pacific. In Sliter, W.V., Bé, A.W.H., and Berger, W.H. (Eds.), Dissolution of Deep-Sea Carbonates. Spec. Publ. Cushman Found. Foraminiferal Res., 13:87-113.

Schneiderman, N., 1973. Deposition of coccoliths in the compensation zone of the Atlantic Ocean. In Smith, L.A., and Hardenbol, J. (Eds.), Proc. Symp. on Calcareous Nannofossils. Soc. Econ. Paleontol. Mineral., Gulf Coast Sect., $140-151$.

Zimmerman, H.B., Shackleton, N.J., Backman, J., Kent, D.V., Baldauf, J.G., Kaltenback, A.J., and Morton, A.C., 1984. History of Plio-Pleistocene climate in the northeastern Atlantic, Deep Sea Drilling Project Hole 552A. In Roberts, D.G., Schnitker, D., et al., Init. Repts. DSDP, 81: Washington (U.S. Govt. Printing Office), 861-875.

\footnotetext{
* Abbreviations for names of organizations and publications in ODP reference lists follow the style given in Chemical Abstracts Service Source Index (published by American Chemical Society).
}

Date of initial receipt: 16 March 1992

Date of acceptance: 10 December 1992

Ms 133SR-228 